\title{
Genetic Determination of Sensitivity to Salt Hypertonicity in Escherichia coli $\mathrm{K} 12$
}

\author{
By H. NAKAMURA \\ Biological Institute, Faculty of Science, Konan University, Kobe 658, Japan
}

(Received 22 February 1977; revised 9 May 1977)

Many Gram-negative non-halophilic bacteria, including Escherichia coli, are plasmolysed when suspended in high salt solutions. This observation has been interpreted as evidence for the presence of an osmotic barrier in the plasma membrane, impermeable to salt (Larsen, 1962). The phospholipid bilayer constituting the plasma membrane must interfere with the penetration of $\mathrm{Na}^{+}$ions. However, any fundamental differences in ion permeability between bacterial strains must be determined by the membrane proteins specific to the strain (see Koh, 1975).

An acriflavine (AF) sensitivity mutation ( $a c r A$ ) lying at min Io on the $E$. coli chromosome (Nakamura, Tojo \& Greenberg, 1975) determines the loss of a protein (referred to as acr $A^{+}$ protein) of the plasma membrane (Nishimukai et al., 1973). The purpose of the present work was to examine whether the $a c r A^{+}$protein is responsible for cell sensitivity to salt.

All strains used were derivatives of $E$. coli KI2. The genotypes of N43 and N90 are acr $A$ and $\mathrm{acrA}^{+}$(AF-resistance) respectively (Nakamura, 1965). Suppressed AF-resistant revertants, N2307, N2308 and N2309, and a true revertant N23IO of N43 were described previously (Nakamura, 1974). The salt-resistant mutant $\mathrm{N} 2800$ of $\mathrm{N} 43$ was spontaneous and was isolated after I I transfers in PGY medium with $\mathrm{NaCl}$ added to $5.3 \%(\mathrm{w} / \mathrm{v})$.

Basal medium PGY, which contained $0.3 \% \mathrm{NaCl}$, was prepared as described previously (Nakamura, 1965). The $\mathrm{pH}$ was adjusted to 7.8 when the medium contained AF and to $\mathrm{pH} 7 \cdot 4$ without the drug. PGY medium of double strength was used when made hypertonic with $\mathrm{NaCl}, \mathrm{KCl}$ or sucrose. For solid media, powdered agar was added to $\mathrm{I} \cdot 5 \%(\mathrm{w} / \mathrm{v})$.

Freshly grown cells of strains N43 and N9O were inoculated into PGY medium containing $5.3 \% \mathrm{NaCl}$ and incubated at $37^{\circ} \mathrm{C}$. Samples were withdrawn at regular intervals and plated on to PGY agar for determination of the viable count. Figure I shows that strain N43 is more sensitive to salt hypertonicity than N9O.

When strains N2307, N2308, N2309 and N23Io were plated on to PGY agar plates containing $\mathrm{NaCl}$ at varying concentrations $(0.3$ to $5.3 \%$ and compared with control strains $\mathrm{N} 43, \mathrm{~N} 90$ and $\mathrm{N} 2800$, it was found that the AF-resistant revertants were also resistant to salt.

We then attempted to find out whether mutants selected for resistance to salt hypertonicity are also resistant to AF. Freshly grown cells of N2800 and N43 (as controls) were

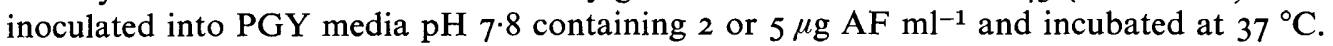
The results showed that $\mathrm{N} 2800$ was significantly more resistant to AF compared with $\mathrm{N} 43$. This strongly suggests that sensitivity to salt and AF is determined by the same gene, acr $A$.

An experiment was performed to ascertain whether resistance of $a c r A^{+}$strains to high concentrations of salt is related to high osmotic pressure or whether it is specific to $\mathrm{Na}^{+}$ions. When fresh cells of $\mathrm{N} 43$ and N9O were cultivated in PGY medium containing $\mathrm{I} \cdot 2 \mathrm{M}$-sucrose, the latter strain had a significantly higher growth rate than the former. It can therefore be concluded that at least part of the salt resistance determined by the $a c r A^{+}$membrane protein is an expression of resistance to high osmotic pressure.

The specificity of the acr $A^{+}$function for resistance to $\mathrm{Na}^{+}$and $\mathrm{AF}$ was next examined. Overnight cultures of strains N43, N90, N2800 and N2309 were plated on PGY agar plates 


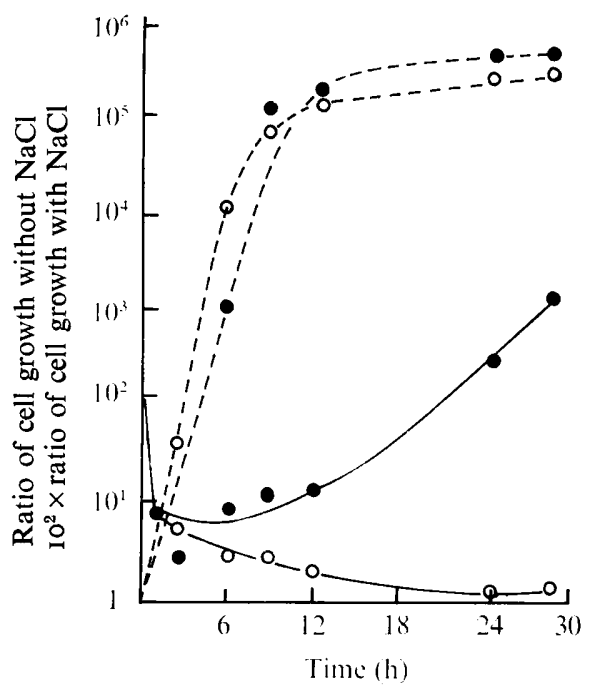

Fig. I. Salt sensitivity of $\operatorname{acr} A$ and $a c r A^{+}$strains. Strains N43 $(\bigcirc)$ and N90 (O) were inoculated into PGY medium with $\mathrm{NaCl}$ at $5.3 \%(-)$ or without $\mathrm{NaCl}(---)$.

containing varying concentrations $[0.8$ to $12.8 \%(\mathrm{w} / \mathrm{v})]$ of $\mathrm{KCl}$. The results showed that bacterial sensitivity to $\mathrm{KCl}$ did not correlate with those for $\mathrm{NaCl}$ and $\mathrm{AF}$.

The acr $A$ gene determines sensitivity to basic dyes including AF (Nakamura, I965), and its mutant allele directs an increased uptake of the dyes (Nakamura, 1966). It might be postulated that more $\mathrm{Na}^{+}$ions penetrate through the membrane of the mutant than through that of the $\operatorname{acr} A^{+}$strain in high salt solutions. This is in accordance with recent results which suggest that in $E$. coli and other non-halophilic bacteria, the intracellular machinery is protected from the high salt environment by the plasma membrane barrier (Larsen, I962, 1967; Baley \& Kusher, 1964; Measures, 1975). Therefore, E. coli cells will become hypersensitive when the $a c r A^{+}$protein, which may be a component of the membrane barrier against salt, is lost by mutation.

I wish to thank Dr J. Ashida for valuable suggestions. This work was supported in part by a grant from the Ministry of Education of Japan.

\section{REFERENCES}

BAYLEY, S. T. \& KuSHNER, D. J. (I964). The ribosome of the extremely halophilic bacterium Halobacterium cutirubrum. Journal of Molecular Biology 9, 654-669.

Kон, T. Y. (1975). Studies on the 'osmophilic' yeast Saccharomyces rouxii and an obligate osmophilic mutant. Journal of General Microbiology 88, IO I-I I4.

LARSEN, H. (1962). The Bacteria, vol. 4, p. 297. Edited by I. C. Gunsalus and R. Y. Stanier. New York: Academic Press.

LARSEN, H. (1967). Biochemical aspects of extreme halophilism. Advances in Microbial Physiology r, 97-132.

Measures, J. C. (1975). Role of amino acids in osmoregulation of non-halophilic bacteria. Nature, London, 257, 398-400.

NakamuRA, H. (1965). Gene-controlled resistance to acriflavine and other basic dyes in Escherichia coli. Journal of Bacteriology 90, 8-I4.

NaKamura, H. (1966). Acriflavine-binding capacity of Escherichia coli in relation to acriflavine sensitivity and metabolic activity. Journal of Bacteriology 92, 1447-1452.

Nakamura, H. (1974). Plasmid-instability in acr A mutants of Escherichia coli KI2. Journal of General Microbiology 84, 85-93.

Nakamura, H., Tojo, T. \& Greenberg, J. (I975). Interaction of the expression of two membrane genes, acr $A$ and $p l s A$, in Escherichia coli. Journal of Bacteriology 122, 874-879.

Nishimukai, H., Arakatsu, Y., Suganuma, A. \& Nakamura, H. (1973). Missing mutation of the plasma membrane protein in Escherichia coli (abstract). Japanese Journal of Genetics 48 , 436. 